\title{
Students' Competence in Cognitive Process and Knowledge in Biology Based on Curriculum Used in Indonesia
}

\section{Paidi Paidi}

Assoc. Prof., Faculty of Mathematics and Natural Science, Universitas Negeri Yogyakarta (Yogyakarta State University), Indonesia, paidi@uny.ac.id

\section{Ixora Sartika Mercuriani}

Dr., Faculty of Mathematics and Natural Science, Universitas Negeri Yogyakarta (Yogyakarta State University), Indonesia, ixomerc@uny.ac.id

\section{Bambang Subali}

Dr., Faculty of Mathematics and Natural Science, Universitas Negeri Yogyakarta (Yogyakarta State University), Indonesia, bambang.subali@gmail.com

This research aim was to reveal the profile of competence in cognitive process and knowledge of grade 11 students of Indonesia's senior high school (SHS) on Biology in relation to the types of the curriculum implemented by the schools. The data were collected using test and self-report inventory technique. The research sample included 1,827 students spread across in five regions/districts of Indonesia. The data were analyzed descriptively using central-tendency and dispersion, and inferentially using independent sample t-test. The findings showed that the students' competence in cognitive process and knowledge in Biology subject is not satisfactory. With regards to the high-level cognitive process of analyzing, evaluating, and creating ( $\mathrm{C} 4, \mathrm{C} 5$, and $\mathrm{C} 6)$, there is a tendency that Curriculum 2013 is more effective than Curriculum 2006. Curriculum 2013 was also (tend to) more effective to develop the metacognitive knowledge especially for aspect of regulation of cognitive, Curriculum 2013 was also more effective than Curriculum 2006.

Keywords: cognitive process and knowledge mastery, biology curriculum

\section{INTRODUCTION}

For the last two decades education experts have tried to determine the abilities and skills needed to be successful in their work and life in the $21^{\text {st }}$ century (Anderson \& Krathwohl, 2001; Holtzman et al., 2011; Ledward \& Hirata, 2011; Suto \& Eccles, 2014). Competences in cognitive process that include analyzing, evaluating, and

Citation: Paidi, P., Mercuriani, I. S., \& Subali, B. (2020). Students' Competence in Cognitive Process and Knowledge in Biology Based on Curriculum Used in Indonesia. International Journal of Instruction, 13(3), 491-510. https://doi.org/10.29333/iji.2020.13334a 
creating knowledge are very important for students (Anderson \& Krathwohl, 2001). Results of review published by Suto \& Eccles (2014) show that competences of cognitive process and knowledge stated by the Anderson \& Krathwohl (2001) are still relevant to the skills needed in the 21st Century. Some of the 21st Century skills identified by program of Assessment and Teaching of 21st Century Skills (ATC21S) can be captured by the revised taxonomy of the cognitive domain (Anderson and Krathwohl, 2001), including creativity and critical thinking skills (Suto \& Eccles, 2014). Ledward \& Hirata (2011) stated that such ability and skills lead to knowledge, literacy, and skills that prepare a person to face challenges and opportunities in the $21^{\text {st }}$ century era. More explicitly, Ledward \& Hirata (2011) state that it is very important for someone to be able to search, synthesize, and communicate information to work collaboratively to solve complex problems and produce new knowledge through the use of various innovative technologies. Holtzman et al. (2011) also identified some skills those are needed for success in work in the 21 st century, some of the skills are managing time, interpersonal skills, and thinking creatively to solve problems.

Indonesian government considered the competence in cognitive process and knowledge very important for high school students. Graduates' competency standards and content standards are contained in Curriculum 2006 and Curriculum 2013. The two curricula applied in Indonesia in the last decade require the importance of high school students to master the ability of thought processes or cognitive processes and knowledge as stated by Anderson \& Krathwohl (2001).

Curriculum 2006 and Curriculum 2013 are similar that both are competency-based and developed from the National Competency Standards and Content Standards. Although departing from the same National Competency Standards and the Content Standards, Curriculum 2006 is more relevant and focuses more on developing the potential and diversity of schools and regions. It focuses on developing potential, intelligence, and students' interests. It also focuses on the socio-cultural conditions of the communities around the school. Curriculum 2013, on the other hand, was developed centrally, it was not based on the potential of schools, regions, and communities around the school. It focuses more on developing a scientific approach on all subjects and at all levels of education (Uce, 2016). It also recommends the use of several innovative learning models, such as problem-based learning, project-based learning, inquiry-based learning, and discovery-based learning.

The competence in cognitive process and knowledge is a revision of Bloom's 6 level cognitive abilities (Anderson \& Krathwohl, 2001), formerly known as Bloom's cognitive taxonomy. In the revised taxonomy, Anderson \& Krathwohl (2001) illustrate the intersections of cognitive process $(\mathrm{C} 1=$ remembering, $\mathrm{C} 2=$ understanding, $\mathrm{C} 3=$ applying, $\mathrm{C} 4=$ analysing, $\mathrm{C} 5=$ evaluating, and $\mathrm{C} 6=$ creating) and cognitive product dimensions or knowledge (K1=factual knowledge, K2=conceptual knowledge, K3=procedural knowledge, and $\mathrm{K} 4=$ metacognitive knowledge). Thus, there are 24 intersections of cognitive processes and cognitive products or knowledge $(\mathrm{C} 1 \mathrm{~K} 1, \mathrm{C} 1 \mathrm{~K} 2, \mathrm{C} 1 \mathrm{~K} 3, \mathrm{C} 1 \mathrm{~K} 4$, $\mathrm{C} 2 \mathrm{~K} 1, \mathrm{C} 2 \mathrm{~K} 2, \mathrm{C} 2 \mathrm{~K} 3, \mathrm{C} 2 \mathrm{~K} 4, \ldots ., \mathrm{C} 6 \mathrm{~K} 1, \mathrm{C} 6 \mathrm{~K} 2, \mathrm{C} 6 \mathrm{~K} 3, \mathrm{C} 6 \mathrm{~K} 4)$. The intersection allows and inspires teachers and educators in choosing of teaching and learning activities. 
Tutkun et al. (2012) agreed with the idea that the intersection empowers teachers and educators to identify which knowledge they expect students to determine and choose, and which cognitive process dimension is used. A learner can remember factual knowledge and procedural knowledge, understand conceptual knowledge, analyze metacognitive knowledge, and/or evaluate metacognitive knowledge. According to Anderson \& Krathwohl (2001), meaningful learning provides learners with the knowledge and cognitive processes they need for successful problem solving.

This intersection brings benefits to teachers in designing learning activities for their students. In line with Anderson \& Krathwohl's ideas, Tutkun et al. (2012) say that this intersection enables teachers to identify which knowledge they expect their students to master and to establish the dimensions of cognitive processes developed in students. A student may be facilitated to recall factual or procedural knowledge, to understand conceptual or metacognitive knowledge, or perhaps to analyze factual or metacognitive knowledge. The ideas of Anderson \& Krathwohl (2001) are supported by Dettmer (2006) and Wu et al. (2016). It is well founded that Anderson \& Krathwohl (2001) link this cognitive taxonomy to the types of learning and assessment (Dettmer, 2006). According to $\mathrm{Wu}$ et al. (2016), the intersection of process ability and cognitive products of the students will stimulate the forms of student learning activities and the kinds of relevant assessments that teachers can choose.

Nitko \& Brookhart (2011) also support the principles applied in the revised Bloom's taxonomy. The number of intersections of the levels of cognitive processes and knowledge will create a wide range of learning and assessment activities. Thus, the revised Bloom's taxonomy will provide additional types of abilities/behaviors that should be established in lesson planning. According to Nitko \& Brookhart (2011), the use of this taxonomy can help students improve their understanding of the importance of an ability (behavior) assigned in the lesson plan. Teachers should use this taxonomy to set learning goals, which will make it easier to set learning experiences and prepare relevant assessment instruments (Dettmer, 2006; Haolader et al, 2015). So far, neither the information about the mastery of the cognitive process and knowledge of high school students, especially in biology subject, nor the information about high school students' thinking skills in remembering, understanding, up to creating in Curriculum 2006 and Curriculum 2013, are available. The students' mastery level of factual knowledge, conceptual knowledge, up to the metacognitive knowledge, in relation to the curriculum used is still unknown. The breadth of the Indonesian territory and various characteristics of the communities across various regions/districts also need to be considered as a variable/contributor to the competence of the cognitive process and knowledge of high school students.

In fact, biology has complex and varied objects and themes of problems, from molecular and cellular objects to diversity, genetic continuity, and the evolution of living things. The complexity of these objects and problems enable biology to be very appropriate as materials for students to improve their thinking skills (Mazzocchi, 2008). Direct observation of objects and problems using practical scientific inquiry outside the classroom are fundamental to an understanding of the nature of science as well as a 
source of inspiration and motivation (Howarth \& Slingsby, 2006). On the other hand, in Indonesia, mastery of a number of biology topics is still a problem up to the bachelor level due to the abstract and complex nature of the material (Fauzi \& Fariantika, 2018). The biology learning difficulty is also found in several other countries, such as in Turkey (Çimer, 2011) and Nigeria (Agboghoroma \& Oyovwi, 2015).

The study on the mastery of competence of cognitive process and knowledge of high school students in Indonesia, in relationship to the types of curriculum used is urgent. Even though it has been more than 4 years since Curriculum 2006 and Curriculum 2013 were implemented, there is no information regarding the achievement of cognitive process and knowledge of high school students. The study of the effectiveness of these two curricula for the achievement of cognitive process and knowledge abilities also has not existed, especially in high school biology. This research is urgent to provide empirical evidence of the effectiveness of Curriculum 2013 to improve students' thinking abilities, so that all schools use Curriculum 2013 as recommended by the government. Currently in Indonesia, some schools are still using the Curriculum 2006 for several reasons, including 1) teachers' difficulties to implement Curriculum 2013, 2) government permission to schools to still use the curriculum 2006 when they are not ready to implement Curriculum 2013, and 3) lack of evidence in the effectiveness of Curriculum 2013. In fact, until 3 years after the plan to implement Curriculum 2013 to replace the Curriculum 2006, some schools still use Curriculum 2006 (Kustijono \& Wiwin, 2014; Ahmad, D. \& Mardiana, 2014; Festiyed, 2015). This study, therefore, is intended to gather information about the effectiveness of Curriculum 2013 related to the achievement of cognitive process skills and knowledge, and to determine the effectiveness of the scientific approach to cognitive processes and knowledge of high school students in biology.

\section{Focus and Aim of Research}

This research investigates the real conditions or competency profiles in cognitive process and knowledge of $11^{\text {th }}$ grade high school students in Indonesia in the academic year of 2017/2018. The profiles will be analyzed in relation to the curriculum used in schools. The results of this study are expected to be able to provide information about the achievement of the competence in cognitive process and knowledge of high school students as a consideration for the government and schools to improve biology learning process. They are also expected to contribute to fulfill the needs for Curriculum 2013, to be implemented intensively and comprehensively in high schools in Indonesia.

\section{METHOD}

\section{Research Design}

This research was a quantitative survey research. The research that was conducted in April-July 2017, investigated the profiles of competence in cognitive process and knowledge of grade 11 students of Indonesia's on biology. A comparison of the students' profiles related to difference of curricula would also be accomplished,. In this comparison, two groups of SHS students taken from SHSs taught using different curriculum would be chosen and determined. 


\section{Population and Sample}

The population of research was all Senior High School (SHS) students in Indonesia. The research sample contained 1,827 students, selected using the multistage random sampling. In the first stage, five provinces were randomly selected from the 34 existing provinces in Indonesia. The selected provinces were Lampung, Yogyakarta Special Region, West Nusa Tenggara (NTB), East Java, and East Nusa Tenggara (NTT) provinces. In the second stage, one district was randomly selected from all existing districts in each province. The selected districts were West Lampung, Kulonprogo, Pacitan, Central Lombok, and Ende districts. In the third stage, three SHSs that have implemented Curriculum 2006 and other three SHSs those have implemented Curriculum 2013 were taken from each district. The last stage of the sampling was determined randomly consisting of one class from each selected SHS, resulting in 30 SHSs. The 4 stages of sampling selected 1827 students from the 30 selected SHSs.

\section{Data Collection and Analyses}

The research instruments used to collect the data were tests to measure the intersections of competence in cognitive process and knowledge. The tests were multiple-choice tests and description objective tests. The multiple-choice tests were used to measure the 15 types of intersection. The intersections were composed from 5 levels of cognitive process ( $\mathrm{C} 1, \mathrm{C} 2, \mathrm{C} 3, \mathrm{C} 4$, and $\mathrm{C} 5)$ and the 3 levels of knowledge (K1, K2, and $\mathrm{K} 3$ ). Meanwhile, the description objective tests were used to measure the intersections of the C6 cognitive processes and the three levels of knowledge (K1, K2, and K3). So, the data about competence scores in cognitive process and knowledge include the C1K1, C1K2, C1K3, C2K1, C2K2, C2K3, C3K1, C3K2, C3K3, C4K1, C4K2, C4K3, C5K1, C5K2, C5K3, C6K1, C6K2, and C6K3. Specifically, the metacognitive knowledge (K4) was measured separately using the Metacognitive Awareness Inventory (MAI), developed by Paidi (2009) that was modified from Stewart et al. (2007) \& Panaoura \& Philippou (2006).

All these tests were developed and validated in the previous research using the Quest program to analyze test items by IRT approach. The mean and standard deviation of the INFIT MNSQ of the multiple choice tests were 1.00 and 0.02 , with the reliability of 0.98 . The mean and standard deviation of the INFIT MNSQ of the description objective tests were 1.00 and 0.24 , with reliability of 0.93 . Those data showed that the tests were in the high categories. Instrument to measure the K4 element (metacognitive knowledge), i.e Metacognitive Awareness Inventory (MAI), were also in good quality with the reliability index of 0.91 .

The data were analyzed descriptively and inferentially. The descriptive analysis, using central-tendency and dispersion, attempted to find out the profile of the competence in cognitive process and knowledge of high school students, and to capture the distribution per level of cognitive process and knowledge. The interpretation of the achievement rate of cognitive process and knowledge was attributed to the criteria/categories adapted from Ebel \& Firsbie (1991) presented in Table 1. 
Table 1

Scores and Categories of Students' Competence in Cognitive Process and Knowledge

\begin{tabular}{ll}
\hline Range of Score & Students' competence in cognitive process and knowledge \\
\hline $75<\mathrm{X}$ & Excellent \\
$58.35<\mathrm{X} \leq 75$ & Good \\
$41.65<\mathrm{X} \leq 58.35$ & Fair \\
$25<\mathrm{X} \leq 41.65$ & Poor \\
$\mathrm{X} \leq 25$ & Very Poor \\
\hline
\end{tabular}

The inferential analysis in the form of the independent samples $t$-test was done to determine the achievement differences of students from across districts as well as from schools implementing either Curriculum 2006 or Curriculum 2013, when parametric inferential analysis requirements, such as the normality of data distribution, and the homogeneity of the variance, were fulfilled. The $t$-test was also carried out to see the difference of each achievement level of cognitive process and knowledge between schools implementing the two curricula. In this case, this analysis was performed for lower order cognitive process ability (LOTS: C1, C2, and C3), higher order cognitive process ability (HOTS: C4, C5, and C6), the levels of factual-conceptual (K1-K2) knowledge, and the levels of procedural knowledge (K3). As done in the instrument for measuring the ability of cognitive process and knowledge, in which different instruments were used to measure metacognitive knowledge elements, the presentation and analysis of the data were also performed separately. Moreover, the data on the achievement of metacognitive knowledge ability were presented and analyzed descriptively.

\section{FINDINGS}

\section{Achievement of Competence in Cognitive Process and Knowledge}

Table 2 shows a general profile of the competence in cognitive process and knowledge in the forms of mean, standard deviation, and minimum and maximum scores calculated from all sample.

Table 2

General Profile of Mean and Standard Deviation of Students' Competence in Cognitive Process and Knowledge Score

\begin{tabular}{ll}
\hline Statistic & Score \\
\hline Mean & 47.59 \\
Standard deviation & 9.70 \\
Minimum Score & 16.8 \\
Maximum Score & 70.4 \\
\hline
\end{tabular}

Table 2 shows that, in general, the grade 11 Science students' competence in cognitive process and knowledge is in the Fair category, with the mean score of 47.59 on a 100 point scale and the standard deviation of 9.70. This achievement score is in a big score range from 16.8 to 70.4 . The range indicates that the students' competence is so heterogeneous. In the context of learning standard, which is one of the principles of Curriculum 2006 and Curriculum 2013, the achievement scores show that most students 
have not reached the standard. In other words, many students find it difficult to achieve the cognitive products and process competence set by the government.

The general profile of the competence in cognitive process and knowledge of grade 11 science students in Indonesia, need to be elaborated to the competence achievements in each intersection of the competence in cognitive process and knowledge. Average of score of the abilities intersections that have been composed from 5 levels of cognitive process $(\mathrm{C} 1, \mathrm{C} 2, \mathrm{C} 3, \mathrm{C} 4$, and $\mathrm{C} 5)$ and the 3 levels of knowledge (K1, K2, and $\mathrm{K} 3$ ) abilities, shown in the Table 3. In the Table 3, would be also displayed the average of score according to the type of curriculum used, the Curriculum 2006 and Curriculum 2013.

Table 3

Average of Competence Score on Each Intersection of the Competence in Cognitive Process and Knowledge on Different Curricula

\begin{tabular}{llll}
\hline & \multicolumn{2}{l}{ Average Score } & \\
\cline { 2 - 4 } Intersection & All Curriculum & Cur-2006 & Cur-2013 \\
\hline C1K1 & 67.04 & 65.7 & 68.2 \\
C1K2 & 65.51 & 63.6 & 67.1 \\
C1K3 & 60.61 & 56.1 & 64.9 \\
C2K1 & 59.15 & 54.1 & 64.2 \\
C2K2 & 57.61 & 53.3 & 61.9 \\
C2K3 & 56.84 & 54.1 & 59.6 \\
C3K1 & 58.05 & 52.5 & 63.6 \\
C3K2 & 58.45 & 56.5 & 60.4 \\
C3K3 & 53.69 & 42.0 & 65.1 \\
C4K1 & 35.60 & 30.4 & 40.8 \\
C4K2 & 40.95 & 37.3 & 44.6 \\
C4K3 & 38.50 & 34.4 & 42.6 \\
C5K1 & 35.28 & 32.8 & 37.9 \\
C5K2 & 35.02 & 33.2 & 36.8 \\
C5K3 & 38.15 & 34.2 & 42.1 \\
C6K1 & 31.01 & 24.5 & 37.7 \\
C6K2 & 32.59 & 30.3 & 34.6 \\
C6K3 & 32.50 & 24.6 & 40.4 \\
\hline
\end{tabular}

Table 3 showed that score of competence in cognitive process and knowledge of the SHS student in Indonesia varies among intersections of these competences, from the average of 32.5 (with a Poor category) to 67.04 (with a Good category). The score tends to decrease as the level of cognitive processes and knowledge increases. There is a tendency to increase cognitive levels $(\mathrm{C})$ tend to be followed by decreasing the scores. Likewise, the addition of knowledge level $(\mathrm{K})$, tends to be followed by a decrease the score.

This means, increasing the level of test questions that have been used, really shows an increase in the level of competence that is increasingly difficult for students to master. Increasing the level of the LOTS measurement questions towards HOTS, increasing the level of the measurement questions for mastering factual knowledge to conceptual and 
procedural actually shows an increase in the level of competence that is increasingly difficult for students to master. This is interesting to analyze further to see the significance of differences competence in cognitive process and knowledge.

In the context of mastery learning, the achievement scores of competence in cognitive process and knowledge of the students are still far from the minimum standard of mastery learning, is 76. The low achievement scores of high school students in Indonesia, especially in the Biology subject, need to be further analyzed to see the detail of this achievement score as well as to observe the effectiveness of the use of Curriculum 2013.

\section{Competence in Cognitive Process and Knowledge in Relationship to the Implemented Curricula}

Table 4 shows the data on the achievement test on cognitive process and knowledge competence based on the implemented curricula followed by the data analysis.

Table 4

The Test Scores of Competence in Cognitive Process and Knowledge on Different Curricula

\begin{tabular}{llll}
\hline Variable & Average Score & Category & Different-Test Significance \\
\hline Curriculum 2013 & 51.83 & Fair & \\
Curriculum 2006 & 43.34 & Fair & Significantly different $(\mathrm{p}<0.05)$ \\
\hline
\end{tabular}

Table 4 shows that in statistics the scores of competence in cognitive process and knowledge in the high schools implementing Curriculum 2013 are significantly different from the ones with Curriculum 2006 although same criteria are used. The competence in cognitive process and knowledge scores of the students of high school implementing Curriculum 2013 are better than those of the students of the high schools implementing Curriculum 2006. The comparison was done in general, including the research districts in Indonesia which have very different background in both the quality and quantity of the aspects of human resources and infrastructures supporting the implemented curricula. The variety of districts which affects the effectiveness of curricula is ascertained by analyzing the data on the high school students' competence in cognitive process and knowledge in each district. The comparison was to determine the achievement differences of students from across districts. Results of the comparison are presented in Table 5. 
Table 5

The Cognitive Competence Scores at Cognitive Process and Knowledge Mastery in Five Districts in Indonesia According to the Curriculum Used

\begin{tabular}{|c|c|c|c|c|c|c|c|c|c|c|}
\hline \multirow[b]{3}{*}{ Statistic } & \multicolumn{10}{|c|}{ The Sample Districts } \\
\hline & \multicolumn{2}{|c|}{$\begin{array}{l}\text { Ende District } \\
\text { (East Nusa }^{\text {Tenggara) }}{ }^{\text {ns }}\end{array}$} & \multicolumn{2}{|c|}{$\begin{array}{l}\text { Central Lombok } \\
\text { (West Nusa }^{\text {Tenggara) }} \\
{ }^{\text {ns }}\end{array}$} & \multicolumn{2}{|c|}{$\begin{array}{l}\text { Pacitan (East } \\
\text { Java)* }\end{array}$} & \multicolumn{2}{|c|}{$\begin{array}{l}\text { Kulonprogo } \\
\text { (Yogyakarta } \\
\text { Special } \\
\text { Region)* } \\
\end{array}$} & \multicolumn{2}{|c|}{$\begin{array}{l}\text { West Lampung } \\
\text { (Lampung) }^{\mathrm{ns}}\end{array}$} \\
\hline & CUR1 & CUR2 & CUR1 & CUR2 & CUR1 & CUR2 & CUR1 & CUR2 & CUR1 & CUR2 \\
\hline Mean & 38.61 & 39.89 & 41.02 & 41.88 & 44.61 & 51.10 & 45.10 & 51.04 & 40.63 & 41.82 \\
\hline $\begin{array}{l}\text { Standard } \\
\text { dev. }\end{array}$ & 5.71 & 8.74 & 9.26 & 12.24 & 9.72 & 8.32 & 9.46 & 1.08 & 8.12 & 7.09 \\
\hline
\end{tabular}

Notes:

ns $=$ not significant different, between Mean Score on Curriculum 2013 and Cur2006

* = significant difference, between Mean Score on Curriculum 2013 and Curriculum 2006

CUR1=Curriculum 2006

CUR2=Curriculum 2013

In the Table 5 it appears that, in the two target districts of research, are in Pacitan (East Java) and Kulonprogo Districts (Yogyakarta Special Region), there are differences in the scores of competence in cognitive process and knowledge of high school students in biology subjects between the two curriculums used. In Pacitan and Kulonprogo Regencies, the scores of competence in cognitive process and knowledge of high school students using Curriculum 2013 were better than those of SMA who used the 2006 Curriculum. While in the other three districts, competence in cognitive process and knowledge scores did not differ significantly between the two types of curriculum used.

\section{The Differences of Competence in Cognitive Process in Relation to LOTS and HOTS based on the Types of Curricula}

In the previous Table 3 there a trend the increasing the level of test questions that have been used, really shows an increase in the level of competence that is increasingly difficult for students to master. Increasing the level of the LOTS measurement questions towards HOT, increasing the level of the measurement questions for mastering factual knowledge to conceptual and procedural actually shows an increase in the level of competence that is increasingly difficult for students to master. Table 6 shows the result of the data analysis of the detailed LOTS competence in cognitive process and knowledge based on the levels of cognitive process according to the types of curricula. 
Table 6

The Score of Competences in Cognitive Process and Knowledge based on the Types of Curricula

\begin{tabular}{llllll}
\hline \multirow{2}{*}{ Competence } & Curriculum & Mean & StDev & Category & $\begin{array}{l}t \text {-Test } \\
\text { Significance }\end{array}$ \\
\hline \multirow{2}{*}{ C1-C3 ${ }^{1)}$} & Curriculum 2013 & 62.97 & 2.87 & Good & not significant \\
& Curriculum 2006 & 55.36 & 6.81 & Fair & $(\mathrm{p} \geq 0.05)$ \\
& Curriculum 2013 & 39.69 & 6.19 & Poor & significant \\
$\mathrm{C}^{-C} 6{ }^{2)}$ & Curriculum 2006 & 31.33 & 8.37 & Poor & $(\mathrm{p}<0.05)$ \\
& Curriculum 2013 & 51.50 & 7.72 & Fair & not significant \\
$\mathrm{K} 1-\mathrm{K} 2{ }^{3)}$ & Curriculum 2006 & 44.54 & 8.82 & Fair & $(\mathrm{p} \geq 0.05)$ \\
& Curriculum 2013 & 52.48 & 8.61 & Fair & significant \\
$\mathrm{K} 3$ & Curriculum 2006 & 40.95 & 7.98 & Poor & $(\mathrm{p}<0.05)$ \\
\hline
\end{tabular}

Note ${ }^{1}$ ) C1-C3= LOTS, the sum of $\mathrm{C} 1, \mathrm{C} 2$, and $\mathrm{C} 3$

Note $^{2}$ ) C4-C6= HOTS, the sum of $\mathrm{C} 4, \mathrm{C} 5$, and $\mathrm{C} 6$

Note $^{3}$ ) $\mathrm{K} 1-\mathrm{K} 2=$ the sum of $\mathrm{K} 1$ and $\mathrm{K} 2$

$\mathrm{K} 1=$ Factual Knowledge

$\mathrm{K} 2=$ Conceptual Knowledge

K3= Procedural Knowledge

Table 6 shows that there is no significant difference $(\mathrm{p} \geq 0.05)$ in C1-C3 cognitive processes between students from schools using Curriculum 2013 and Curriculum 2016. This can be interpreted that the two types of curriculum contribute relatively the same in building the LOTS in biology subject. Table 6 also shows that there is no significant difference in students' competencies in $\mathrm{K} 1$ and $\mathrm{K} 2$ levels due to the using of the two types of curricula, although this competence tended to be higher among students who learned using Curriculum 2013.

On the other hand, Table 6 showed that the high scores of the HOTS of high school students from schools applying Curriculum 2013 and Curriculum 2006, both are in a Poor category. However, the Curriculum 2013 works better for the HOTS $(\mathrm{p}<0.05)$. Curriculum 2013 also gives a better contribution to achievement of K3. Students from the schools implementing Curriculum 2013 achieved the mean score of 52.48 which falls into the Medium category. Meanwhile, those from schools using Curriculum 2006 achieved the mean score of 40.95 which is in a Low category. This means that Curriculum 2013 works better at the K3 than the school-based curriculum even though when the gained score is still not high enough. So it can be interpreted that the curriculum 2013 gives a better contribution to the competences in cognitive process and knowledge, although the students' mean scores in these competences are still not satisfactory yet.

The Results on the Metacognitive Knowledge Competence of the Students in Indonesia

The findings on the students' metacognitive competence based on metacognitive competence aspects or components are presented in Table 7. 
Table 7

The Profile of Students' Scores at Metacognitive Knowledge Competence based on Metacognitive Knowledge Competence Aspects

\begin{tabular}{lll}
\hline No & Metacognitive Knowledge Competence Aspects and Sub-aspects & Mean \\
\hline 1 & Knowledge of Cognition & 72.12 \\
\hline 2 & Regulation of Cognition & 72.15 \\
\hline
\end{tabular}

Table 7 reveals that the metacognitive competence aspect of knowledge of cognition is 72.12 and that of regulation of cognition is 72.15. The Metacognitive Awareness Inventory (MAI) shows metacognitive competence in the context of self-awareness. The findings show that Indonesian students' metacognitive awareness is high. To realize that the curricula effect to the Indonesian students metacognitive awareness, let us check the following Table 8. This table contains the findings of metacognitive competence analysis of Indonesian students in regards to Curriculum 2006 and Curriculum 2013.

Table 8

Mean of Students' Metacognitive Competence Scores based on the Curriculum used in School

\begin{tabular}{lll}
\hline & \multicolumn{2}{l}{ Type of Curriculum Used in School ${ }^{\mathrm{ns}}$ ) } \\
\cline { 2 - 3 } Metacognitive Competence Aspects & CUR 2006 & CUR 2013 \\
\hline Knowledge of Cognition & 72.04 & 72.20 \\
Regulation of Cognition & 70.66 & 73.64
\end{tabular}

Notes:

$\left.{ }^{\mathrm{ns}}\right)=$ not significant different

CUR 2006 = Curriculum 2006

CUR 2013 = Curriculum 2013

In general, metacognitive abilities of students who study with Curriculum 2006 and students who learn to use Curriculum 2013 look similar. This means that both of these curricula are good enough to provide reinforcement of high school students' metacognitive abilities, even though Curriculum 2013 gives a better reinforcement than Curriculum 2006. The findings of metacognitive competence measurement conducted in 2017 as presented in Table 7 and Table 8 are close to those of previous study in Sleman on the innovative class which implemented Problem-Based Learning complemented by concept mapping as Matacognitive Strategy (Paidi, 2009). In the Paidi's study (2009) found that high school students were engaged in problem-solving activities through the implementation of Problem-Based Learning (PBL) and Concept mapping to understand the whole concept. The integration of concept mapping in PBL is based on Savery's findings (2006). The overview stated that there were several problems in PBL implementation, particularly in the students' lack of understanding of the subject-matter mastery and/or knowledge. Thus, the integration of concept mapping in the implementation of the PBL, is expected to improve the students' competence as a whole, including the metacognitive knowledge. The findings of the study, as well as its comparison to current study (2017) are shown in Table 9. 
Table 9

Description of Metacognitive Knowledge Achievement based on the Metacognitive Component Aspects and Comparison with the Findings of Innovative Learning*)

\begin{tabular}{llll}
\hline & & Mean & \\
\cline { 3 - 4 } No & Metacognitive Component & $\begin{array}{l}\text { Current Research Result } \\
\left.(2017)^{*}\right)\end{array}$ & $\begin{array}{l}\text { Previous Research } \\
\left.\text { Result }(2009)^{* *}\right)\end{array}$ \\
\hline 1 & Knowled & 72.20 & 75.72 \\
2 & Regulation of Cognition & 73.64 & 72.94 \\
\hline
\end{tabular}

Note: *) Current Research Result (Paidi, 2017), with The Curriculun 2013

**) Previous Research Result (Paidi, 2009) which implemented PBL+ Concept Mapping

In table 9, it can be seen that in general the students' metacognitive competency, who study with Curriculum 2013, in the 2017 research results are relatively similar to the results of previous studies in Sleman, Yogyakarta Special Region, in 2009. The study was conducted in several senior high schools in Sleman district, set in experimental research. One of the treatments in this experiment was the implementation of PBL complemented by concept mapping, which was carried out very intensively for one semester. While curriculum used in some of these senior high schools is Curriculum 2006. However, if we look at the results in Table 9, it can be seen that the metacognitive competencies of students who study with Curriculum 2006 plus PBL complemented by concept mapping tend to be better than those who learn using Curriculum 2013, which is not Intensively applying PBL, especially in the Metacognitive Knowledge aspect. These results indicate that metacognitive abilities, especially the Metacognitive Knowledge aspect, require the support of learning activities that provide a lot of challenges to students' activities and thinking on activities that are intensive.

\section{DISCUSSION}

Findings regarding the general profile of cognitive process skills and knowledge among high school students in Indonesia, as presented in Table 2, Table 3, and Table 4. The tables showed that mean of the achievement of cognitive process and knowledge competence is in so heterogeneous with a Fair category. In Table 4, it can be seen that, even though there are significant differences in competence in cognitive process and knowledge, between students from schools using the 2006 curriculum and the 2013 curriculum, all of these capabilities are not yet classified as good (with a Fair category). Even though the 2013 curriculum has been implemented for around 5 years and moreover the 2006 curriculum, has been applied for more than 10 years in these schools. The thoughts of Anderson \& Krathwohl on cognitive process and knowledge competencies have been accommodated in the 2006 curriculum and 2013 Curriculum. This means that the implementation of the 2006 curriculum and 2013 curriculum, both of which are competency-based curricula, have not effectively improved cognitive process skills and student knowledge.

In the context of mastery learning, the achievement scores of cognitive process and knowledge competence of the students are far from the minimum standard. Some researchers in some countries use a minimum standard of $80 \%$ or a score of 80 on a scale of 100, such as in Africa (Mitee \& Obaitan, 2015; Adeyemo \& Babajide, 2014), 
Asia (Damavandi \& Kashani, 2010), America (Guskey, 2010), Australia (Birhan, 2018), and Europe (Barsuk et al, 2012). This means that the level of standard of high school students in Indonesia at the eleventh grade in terms of the mastery of cognitive process and knowledge competence in the Biology subject is still very low. The use of competency-based curriculum, including Curriculum 2006 and Curriculum 2013 in Indonesia, so far has not been able to help the students achieve the standard of competence of the cognitive process and knowledge. Even however, Curriculum 2013 was designed as a curriculum with a scientific approach, which was believed to be effective in building HOTS students and some other abilities that students required in the $21^{\text {st }}$ century. The low achievement scores of high school students in Indonesia, especially in the Biology subject, need to be analyzed further to see the detail of this achievement score as well as to observe the effectiveness of the use of Curriculum 2013.

Table 5 clearly shows that, although the two curricula have not been able to make students have good cognitive and knowledge process skills, Curriculum 2013 seems to have a better effect. Table 5 also shows the low scores of competence in cognitive process and knowledge in each region of Indonesia. However, there is a tendency of differences in score of cognitive competence in process and product dimensions among high school students in Ende District, Central Lombok, Pacitan, Kulonprogo and West Lampung districts. The achievement scores of students' cognitive competence in Pacitan and Kulonprogo are relatively the same or not significant $(p \geq 0.05)$. Likewise, in Central Lombok and Lampung districts, the results are not significantly different $(p \geq 0.05)$. Meanwhile, the achievement scores of cognitive process and knowledge competence of students in East Java Province and Yogyakarta Special Region Province (DIY) differ significantly $(p<0.05)$ if they are compared to those in Lombok, Lampung, and in East Nusa Tenggara provinces. One of the causes of these differences is related to the implementation of Curriculum 2013. Knowledge ability of cognitive processes and knowledge of high school students in West Lampung (Lampung), Central Lombok (West Nusa Tenggara), and Ende (East Nusa Tenggara) are lower than the abilities of students from Pacitan (East Java) and Kulonporogo (Special Region of Yogyakarta ). In both districts, there are significant differences in cognitive process and knowledge skills between students from schools using Curriculum 2013 and those from schools using Curriculum 2006. In contrast, in 3 districts in West Lampung, Central Lombok, and Ende, these two curricula do not provide a significant difference effect. As found by researchers (Pratiwi \& Hidayat, 2014; Neliti (2016), Pacitan and Kulonprogo regencies are more developed regions in Java, which have better teachers and better learning equipment. While West Lampung, Central Lombok, and Ende are regions that are not yet developed, which still have problems with the adequacy of teachers and equipment for learning. It can be inferred from Table 4 and Table 5 that the effectiveness of Curriculum 2013 in the cognitive process and knowledge achievement is related to the conditions of the districts and/or provinces.

The effectiveness of Curriculum 2013 in two provinces/regions (East Java and Yogyakarta Special Region) is affected by the different perspectives and focuses of both curricula. On the contrary, in the three provinces (East Nusa Tenggara, West Nusa Tenggara, and Lampung), teachers' readiness becomes the factor affecting the 
effectiveness of Curriculum 2013 and Curriculum 2006. As stated in the findings of the research conducted by Qomariyah (2014) in Central Java, even in the second year of implementation, there were teachers who were not ready to implement the curriculum. Similar cases can be easily found in districts which are lack in human resources to implement Curriculum 2013 properly. Thus, it can be concluded that, Curriculum 2013 requires teachers' adequacy and learning equipment to be effective in improving the ability of cognitive processes and knowledge of students.

Okogu (2011) found several factors that influence the effectiveness of a curriculum. One of them is the ability of teachers to carry out learning according to the curriculum demands. Fu \& Sibert (2017), in their research on teachers in the Ohio District, found several factors that influence the implementation of a curriculum. Among of the most important factors is the community support, which is colleague support in planning and implementing learning due to the curriculum. Another factor is teacher knowledge and skills in implementing the curriculum (Fu \& Sibert, 2017).

Syomwene (2013) through her research in Kenya, found that the most important factors that influence the success of curriculum implementation are the adequacy of teachers and learning equipment. The adequacy of teachers includes the adequacy of the number and ability of teachers to be able to teach learning as required by the curriculum (Syomwene, 2013). The adequacy of teacher and learning equipment for the successful implementation of the curriculum, as found by Syomwene (2013), seems to be in line with the low of the successful implementation of Curriculum 2013 in Indonesia, in biology, which is indicated by the low achievement of cognitive and knowledge processing capabilities.

The findings in the Table 6-9 showed that Curriculum 2013 gives better contribution to the development of HOTS and C3 competencies than Curriculum 2006. Teachers' readiness to implement Curriculum 2013 is also considered to affect the competence achievement in several districts in Indonesia (Siskandar, 2016). As a result, Curriculum 2013 is deemed effective to develop reasoning and scientific processing competencies. Curriculum 2013 focuses on reasoning development, scientific processing practices, and habituation to attain competencies in several aspects such as attitude, knowledge, and skills (Uce, 2016). Further, Shawer et al. (2008) points out the principal relationship between curriculum and student learning outcomes which lies in the teacher's ability to develop the curriculum and to bring it to life in the classroom. The same thing is expressed by Siskandar (2016) who found that the contribution of the successful implementation of Curriculum 2013 lies in teachers' readiness to implement the curriculum into student learning activities. Cognitive process is a mental activity of someone who is interpreted as information processing. Information processing includes receiving information and synthesizing it with what has been understood before, storing information and recalling the information when needed (Slavin, 2009). Curriculum 2013 which explicitly emphasizes the scientific development process is certainly more intensive than Curriculum 2006 in encouraging teachers to incorporate the scientific process into students' learning activities. 
The scientific approach established by Curriculum 2013 as a teaching approach in all subjects, including biology, which consists of five stages of scientific activities namely observing, asking, investigating, reasoning, and communicating, is believed to be very effective in building students' thinking and reasoning abilities. Especially with the implementation of innovative teaching models recommended by Curriculum 2013, such as Problem-Based Learning, Inquiry-Based Learning, and Project-Based Learning, many practice the cognitive process of remembering, understanding, applying, analyzing, criticizing, and producing / designing something, it is known to be effective in increasing high-level thinking skills (HOTS). Regarding the effectiveness of some of these teaching models on high-level thinking skills has been proven through many studies, including Paidi (2009), Ahiri et al. (2015); Magsino (2014); and Hugeratt \& Koctam (2014).

Ahiri et al. (2015) summarized that the implementation of the Contextual Teaching and Learning (CTL) strategy gave more effect in improving the higher-order thinking skills (HOTS) of students compared to the implementation of collaborative learning strategy and competitive learning strategy. Magsimo (2014) found that using problem-based learning and working in collaborative groups, students manifested their critical thinking. Learning the application of the scientific method through problem-based learning in a marine biology course fostered higher order thinking skills among students. Hugeratt \& Koctam (2014) conducted a study to examine teaching science by inquiry using case studies and scientific research articles in order to develop the students' HOTS. The study found a significant effect of this learning method on improving HOTS among the participants. Teaching by inquiry focuses on the process by which the student is active. It can be considered that learning provides opportunities for students to recognize problems, practice solving the problems through real activities, cooperative, and collaborative learning to interpret facts and data related to problems. All of these are the essence of Curriculum 2013, to be able to develop high-level thinking skills of high school students.

According to findings in Table 7-9, Indonesian students' metacognitive awareness is high, even higher than the similar study conducted in Turkey. Öz (2016) reported that seven out of ten English student-teachers aged 19-23 years old at the University of Turkey showed the metacognitive awareness aspect of knowledge of cognition of 65 and that of regulation of cognition of 63 . In conclusion, the results of students' metacognitive knowledge in Indonesia are higher than that in Turkey.

The comparison and results of the study, which were showed in Table 9, were in line with the research results conducted by Tosum \& Senocak (2013) and Conley (2014). Tosum \& Senocak (2013) stated that in a short time implementation of Problem-Based Learning (PBL), this teaching model had been highly significant in improving declarative knowledge and information management, the lower level dimensions of metacognitive knowledge. On the other hand, PBL had a low or no effect on the higherlevel dimensions of metacognitive knowledge for students. It can be explained that the higher level of metacognitive knowledge needs enough time to achieve. As has been found by Tosum \& Senocak (2013), Conley (2014) also has been successful in 
improving his students' metacognitive knowledge through the implementation of Problem Based Learning, which facilitates them to do problem-solving, self-assessment, and self-reflection. Both Tosum \& Senocak (2013) and Conley (2014) concluded that enough time and learning intensively are needed to gain high-level metacognitive knowledge.

Finally, curriculum is believed to be influential to the quality of learning process, teachers are in fact a dominant factor in determining whether or not the curriculum is implemented correctly. Sepriyanti (2012) argued that quality education can only occur under the hands of qualified and virtuous teachers. In addition, Sifa (2016) emphasized that the success of learning relies heavily on the seriousness and standards fulfillment of the teachers' competence as required by the government.

\section{CONCLUSION}

The SHS students' achievement on the competencies of cognitive process and knowledge in biology subject of grade 11 in Indonesia are classified medium and have not reached yet the minimal criteria of mastery learning. However, the results showed that students who learn using Curriculum 2013 tend to be better at higher-order thinking skills (HOTS), procedural knowledge, and metacognitive knowledge compared to those who learn using Curriculum 2006. It means that the learning of Biology using innovative teaching models recommended in Curriculum 2013 is considered more effective to help students master the competence in cognitive process and knowledge more properly.

The implications of this research are for the Government of Indonesia, schools, and biology teachers. The curriculum 2013 is proven to have a better contribution in improving the competence of cognitive process and mastery of knowledge, compared to the curriculum 2006. Therefore, the government needs to encourage schools and teachers, especially biology teachers to intensively implement the curriculum 2013. The effectiveness of the curriculum needs to be improved through problem-solving, selfassessment, and self-reflection in learning activities on biology.

\section{ACKNOWLEDGEMENTS}

The researcher would like to thank to Iis Aida, Ajeng Purnama Heny, Temi Ainul Safitri, Veronika V. Shinta, and Tika Mayangsari, students of the postgraduate program, Universitas Negeri Yogyakarta, who gave big contribution in collecting and organizing the research data. Special thank to Basikin, Ph.D who also gave big contribution in reviewing this article.

\section{REFERENCES}

Adeyemo, S. A., \& Babajide, V. F. T. (2014). Effects of mastery learning approach on students'achievement in physics. International Journal of Scientific \& Engineering Research, 5(2), 910-920.

Agboghoroma, T. E., \& Oyovwi, E. O. (2015). Evaluating effect of students' academic achievement on identified difficult concepts in senior secondary school biology in Delta State. Journal of Education and Practice, 6(30), 117-125. 
Ahiri, J., Dunifa, L., Tanduklangi, T., \& Ghani, A. R. A. (2015). The effect of learning strategies on higher-order thinking skills students with different learning. International Journal of Science and Research, 4(9), 1204-1211.

Ahmad, D., \& Mardiana. (2014). Kurikulum 2013 dalam persepsi dan interpretasi guruguru Bahasa Inggris SMA Kota Makassar [Curriculum 2013 in the perceptions and interpretations of English teachers in SHS Makassar City]. Jurnal Pendidikan Bahasa dan Sastra, 13(1), 71-80.

Anderson, L. W., \& Krathwohl, D. R., et al. (Eds.) (2001) A taxonomy for learning, teaching, and assessing: A Revision of Bloom's taxonomy of educational objectives. Allyn and Bacon.

Barsuk, J. H., Cohen, E. R., Vozenilek, J. A., O’Connor, L. M., McGaghie, W. C., \& Wayne, D. B. (2012). Simulation-based education with mastery learning improves paracentesis skills. Journal of Graduate Medical Education, 3(12), 22-27. doi: 10.4300/JGME-D-11-00161.1.

Bialik, M., \& Fadel, C. (2015). Skills for the 21st century: What should students learn? Boston: Center for Curriculum Redesign.

Birhan, A. T. (2018). Effects of mastery learning instruction on engineering students' writing skills development and motivation. Journal of Language and Education, 4(4), 20-30. DOI: 10.17323/2411-7390-2018-4-4-20-30.

Çimer, A. (2011). What makes biology learning difficult and effective: Students' views. Educational Research and Reviews, 7(3), 61-71. DOI: 10.5897/ERR11.205.

Conklin. W., \& Manfro. J. (2012). Higher order thinking skills to develop 21st century learners. Huntington: Shell Education Publishing. Inc.

Conley. D. (2014). Learning strategies as metacognitive factors: A critical review. Eugene. OR: Educational Policy Improvement Center (EPIC).

Considine, G., \& Zappala, G. (2002). Factors influencing the educational performance of students from disadvantaged backgrounds. In T. Eardley, \& B. Bradbury (Eds.), Competing visions: Refereed proceedings of the national social policy conference 2001. SPRC Report 1/02 (pp.91-107). Social Policy Research Centre. University of New South Wales. Sydney.

Damavandi, M. E., \& Kashani, Z. S. (2010). Effect of mastery learning method on performance and attitude of the weak students in chemistry. Procedia Social and Behavioral Sciences, 5, 1574-1579. doi:10.1016/j.sbspro.2010.07.327.

Dettmer P. (2006). New blooms in established fields: Four domains of learning and doing. Roeper Review. ProQuest Education Journals, 28(2), 70

Ebel, R., \& Firsbie, D. (1991). Essentials of education measurement. India: Prentice Hall. 
Fauzi, A., \& Fariantika, A. (2018). Courses perceived difficult by undergraduate students majoring in biology. Biosfer: Jurnal Pendidikan Biologi, 11(2), 78-89.

Festiyed, F. (2015). Studi pendahuluan pengimplementasian kurikulum 2013 dalam mengintegrasikan pendekatan saintifik melalui model inkuiri dan authentic assessment dalam pembelajaran IPA di Kota Padang [A preliminary study on the implementation of the curriculum 2013 in integrating scientific approaches through inquiry models and authentic assessment in learning science in Padang]. Paper Seminar Semirata. Universitas Tanjung Pura, Pontianak, 6-9 Mei. Online article. Retrieved from http://fmipa.unp.ac.id/artikel/.

Fu, Y., \& Sibert, S. (2017). Teachers' perspectives: Factors that impact implementation of integrated curriculum in K-3 classrooms. International Journal of Instruction, 10(1), 169-186.

Haolader, F. A., Ali, Md. R., \& Foysol, K. Md. (2015). The taxonomy for learning, teaching and assessing: Current practices at polytechnics in Bangladesh and its effects in developing students' competences. International Journal for Research in Vocational Education and Training, 2(2), 99-118. doi: 10.13152/IJRVET.2.2.2.

Heong, Y. M., Othman, W., Yunos, J. B. M., Kiong, T. T., Hassan, R., \& Mohamad, M. M. (2011). The level of Marzano higher order thinking skills among technical education students. International Journal of Social Science and Humanity, 1(2), 121-125

Holtzman, D. M., Stockton, R., \& Kraft, E. M. (2011). Skills needed in the 21 st century workplace: A comparison of feedback from undergraduate business alumni and employers with a national study. Business Education \& Accreditation, 3(1), 61-76.

Howarth, S., \& Slingsby, D. (2006). Biology fieldwork in school grounds: a model of good practice in teaching science. School Science Review, 87(320), 99-105.

Hugeratt, M., \& Koctam, N. (2014). Improving higher order thinking skills among freshmen by teaching science through inquiry. Eurasia Journal of Mathematics, Science and Technology Education, 10(5), 447-454.

Kustijono, R., \& Wiwin, E. H. M. (2018). Pandangan guru terhadap pelaksanaan kurikulum 2013 dalam pembelajaran fisika SMK di Kota Surabaya [Teachers' views on the implementation of the 2013 curriculum on physics learning in SMK in Surabaya]. Jurnal Pendidikan Fisika dan Aplikasinya, 4(1), 1-14.

Ledward, B. C., \& Hirata, D. (2011). An overview of $21^{\text {st }}$ century skills. Summary of 21st century skills for students and teachers, by Pacific Policy Research Center. Honolulu: Kamehameha Schools-Research and Evaluation.

Magsino, R. M. (2014). Enhancing higher order thinking skills in a marine biology class through problem-based learning. Asia Pacific Journal of Multidisciplinary Research, 2(5), 1-6.

Mazzocchi, F. (2008). Complexity in biology. European Molecular Biology Organization reports, 9(1), 10-14. 
Mitee, T. L., \& Obaitan, G. N. (2015). Effect of mastery learning on senior secondary school students' cognitive learning outcome in quantitative chemistry. Journal of Education and Practice, 6(5), 34-38

Neliti. (2016). Human development indices by province in Indonesia, 2010-2015 (New method). Jakarta: BPS.

Nitko, A. J., \& Brookhart, S. M. (2011). Educational assessment of student. New Jersey: Pearson Education Inc.

Okogu, J. (2011). Factors affecting the effective implementation of social studies curriculum in Delta state teachers' training colleges. Journal of Research in Education and Society, 2(3), 48-53

Öz, H. (2016). Metacognitive awareness and academic motivation: a cross-sectional study in teacher education context of turkey. Procedia - Social and Behavioral Sciences, $232,109-121$

Paidi. (2009). Pengembangan perangkat pembelajaran dan pengaruhnya terhadap kemampuan metakognitif. pemecahan masalah. dan penguasaan konsep biologi [Developing of the teaching set and its effect to metacognitive competence, problem solving skills, and biology concepts mastery]. Jurnal Pendidikan Biologi UM [The Biology Education Journal, University of Malang], 1(1), 20-29.

Paidi, Djukri, Yulaikah, S., \& Alfindasari, D. (2017). Development of instrument to assess cognitive process and knowledge in biology senior high school. International Journal of Environmental and Science Education, 12(8), 1719-1735

Panaoura, A., \& Philippou, G. (2006). The measurement of young pupils' metacognitive ability in mathematics: the case of self-representation and self-evaluation. Department of Education, University of Cyprus.

Pratiwi, E., \& Hidayat, P. (2014). Analisis pertumbuhan ekonomi dan indeks pembangunan manusia (IPM) provinsi-provinsi di Indonesia (metode kointegrasi) [Analysis of economic growth and human development index (HDI) provinces in Indonesia (cointegration method)]. Jurnal Ekonomi dan Keuangan, 2(2), 14-27.

Qomariyah. (2014). Kesiapan guru dalam menghadapi implementasi kurikulum 2013 [Teacher readiness in facing the implementation of Curriculum 2013]. Jurnal Pendidikan Ekonomi IKIP Veteran Semarang, 2(1), 21-35.

Savery, J. R. (2006). Overview of problem-based learning: Definitions and distinctions. Interdisciplinary Journal of Problem-based Learning, 1(1), 9-18

Sepriyanti, N. (2012). Guru profesional adalah kunci mewujudkan pendidikan berkualitas [Professional teacher is main key toward the qualified education]. Jurnal AlTa'l im [The Al-Ta'l im Journal], 1(1), 66-73 
Shawer, S. F., Gilmore, D., \& Joseph, B. S. R. (2008). Student cognitive and affective development in the context of classroom-level curriculum development. Journal of the Scholarship of Teaching and Learning, 8(1), 1-28

Sifa, A. N. A. (2016). Urgensi kompetensi guru dalam implementasi pendidikan integrative. [The urgency of teacher's competency in implementing of integrative education]. Jurnal At-Ta'dib [At-Ta'dib Journal], 11(1), 109-127.

Siskandar, (2016). Evaluasi implementasi kurikulum 2013 di madrasah aliyah. Cendekia [Evaluating of Curriculum 2013 implementaion in MA]. Cendekia, 10(2), 117-132.

Slavin, R. E. (2009). Educational psychology: Theory and practice. Boston: Allyn and Bacon.

Stewart, P. W., Cooper, S. S., \& Moulding, L. R. (2007). Metacognitive development in professional educators. The Researcher, 21(1), 32-40.

Suto, I., \& Eccles, H. (2014). The Cambridge approach to 21 st century skills: definitions, development and dilemmas for assessment. IAEA Conference, Singapore, 2014. Retrieved from https://www.cambridgeassessment.org.uk/-Images/461811-thecambridge-approach-to-21st-century-skills-definitions-development-and-dilemmas-forassessment-.pdf.

Syomwene, A. (2013). Factors affecting teachers' implementation of curriculum reforms and educational policies in schools: The Kenyan experience. Journal of Education and Practice, 4(22), 80-86

Tosum, C., \& Senocak, E. (2013). The effects of problem-based learning on metacognitive awareness and attitudes toward chemistry of prospective teachers with different academic Backgrounds. Australian Journal of Teacher Education, 38(3), 6173.

Tutkun, O. F., Guzel, D., Koroglu, M., \& Ilhan, H. (2012). Bloom's revized taxonomy and critics on it. The Online Journal of Counselling and Education, 1(3), 23-30.

Uce, L. (2016). Realitas aktual praksis kurikulum: analisis terhadap kbk, ktsp, dan kurikulum 2013 [Actual reality of curriculum practice: Analysis of the Competencebased Curriculum, Curriculum 2006, and Curriculum 2013]. Jurnal Ilmiah Didaktika [Journal of Scientific Didactics],16(2), 216-229. 